\title{
Sphalerite from transgressive and regressive sediments of the Cambro-Silurian supercycle, Baltic Shield
}

\author{
MAURITS LINDSTRÖM \& W. VORTISCH
}

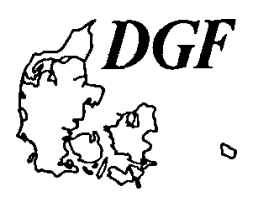

\begin{abstract}
Lindström, M. \& Vortisch, W. 1978: Sphalerite from transgressive and regressive sediments of the Cambro-Silurian supercycle, Baltic Shield. Bull. geol. Soc. Denmark, vol. 26, p. 47-53. Copenhagen, October 1st 1978. https://doi.org/10.37570/bgsd-1978-27-04

A sedimentary micro-vent in Lower Cambrian sandstone, and spar filled cephalopod shells in uppermost Wenlockian barite and dolomite carrying silty pelmicrosparite contain well-developed macroscopic $\mathrm{ZnS}$-mineralization and very little pyrite. As controlling factors are suggested, good permeability, availability in underlying sediment of finely dispersed organic matter with sorbed $\mathrm{Zn}$, and low $\mathrm{S}^{2-}$ activity in the percolating water. Sedimentation was temporarily rather rapid.
\end{abstract}

M. Lindström \& W. Vortisch, Institut für Geologie und Paläontologie, Philipps-Universität, Marburg, Lahnberge, D-3550 Marburg, F.R.G. December 6th, 1977.

Macroscopic zincblende is rare in the Cambro-Silurian of the Baltic Shield. We can report on two cases of sphalerite, both apparently of a relatively early, diagenetic origin. Significantly, they occur in the Lower Cambrian and upper Middle Silurian, in the transgressive and regressive phases of Early Palaeozoic marine sedimentation in northern Europe. Structure and mineralogy of the rocks appear to indicate some interesting restrictions on the interpretation.

For reviews of the Early Palaeozoic of the Baltic Shield, see for instance Lindström 1971 and Magnusson et al. 1960. In the Early Cambrian the sea transgressed on peneplaned terrains of mostly igneous and metamorphic rocks, depositing a sheet of quartzitic to feldspathic sands and silts, and more or less potash-rich clays. During later parts of the Cambrian a regime of black mud, rich in pyrite and organic carbon, became universally established. In the Early Ordovician this was succeeded by mainly limestones, very slowly deposited, of a type that one might characterize as pelagic. In the Middle and Late Ordovician the sedimentation of terrigenous mud accelerated slightly, resulting in a number of shaly members, some of which are graptolithic. Calcareous mounds are a feature of some areas. As in several other regions, the sea obviously withdrew for a relatively short interval at the Ordovician/Silurian transition. Silurian sediments were for the most part deposited in warm, nutrient rich shelf waters of slight to medium depth. This resulted in variable, mainly calcareous fa- cies, ranging from fossiliferous marls through reef and algal limestones, coquinoid bioclastics, oolites and siltstones, to fine to medium grained sandstones. Together with the oolites the latter represent regressive phases (see, e.g., Regnéll \&. Hede 1960). About the Silurian/Devonian transition the sea ultimately withdrew towards the south. At this stage much, if not most, of the Baltic Shield was covered by a flat-lying sheet of Lower Palaeozoic sediments, the thickness of which attained a few hundred metres at the southern border.

\section{A Lower Cambrian specimen}

Sphalerite was found in a 5-6 $\mathrm{mm}$ thick micro-vent transecting a $1-3 \mathrm{~cm}$ thick bed of sandstone belonging to a succession of alternating sandstone and clay beds at the base of the Lower Cambrian "Mickwitzia Sandstone" of Lugnås old millstone quarry (now an open-air museum), Västergötland, Sweden (see, for instance, Hadding 1922). The sandstone rests on a plane surface of gneiss that is kaolinized and somewhat silicified down to a depth of a several tens of centimetres. The basal conglomerate may be some $10-30 \mathrm{~cm}$ thick and contain pebbles of e.g. vein quartz, potash feldspar, clay ironstone, and sandstone with a reddish, ferruginous cement. Then follow several metres of alternating beds of ripple cross-bedded sandstone, mostly a few centimetres thick, and grey, silty kaolinite and illite 
containing clay (X-ray), mostly somewhat thinner than the sandstone beds. The sandstone beds are common in the lowermost metre. The sample comes from this interval.

It is a silty, cross-laminated sandstone with grain-sizes mainly $10-150 \mu \mathrm{m}$ and few grains over $500 \mu \mathrm{m}$. Quartz, feldspar (mainly K-feldspar (X-ray), some plagioclase) and muscovite are the main components. Zircon and tourmaline are not rare, and a few rutiles occur. Electron Probe Analysis (EPA) revealed the presence of $\mathrm{TiO}_{2}$, probably mainly as anatase (by optical and X-ray comparison with Lower Cambrian sandstone in southernmost Sweden, see Vortisch 1975). This mineral is probably authigenic.

Remnants of ferrous sulphide were identified as probably pyrite. The matrix consists of siderite, illitic and kaolinitic clay minerals (X-ray), and yellowish brown colouring matter, presumably ferric oxyhydrate. The latter could not be identified by X-ray and might be present in small quantities. The siderite is seldom clear but appears mixed with clay minerals and brownish colouring substance. In the thin section the sedimentary lamination is seen to consist of aggregates of clastic grains, mostly cemented by quartz, separated by siderite cemented floccules of clay and isolated clastic grains. The siderite has eaten into many of the clastic grains and their quartz cement.

The siderite mostly contains about $0.5 \% \mathrm{Mn}$ by weight (EPA). Mn contents of ca $3-6 \%$ were identified at some spots.

The micro-vent (fig. 1A), presumably a vertical burrow that took over transporting functions between the lower and upper surfaces of the sandstone layer, is distinguished from the latter by its pale greenish grey colour. The content of clay minerals (illite, kaolinite) and microclinelike potash feldspar is appreciably higher, and the quartz and siderite content correspondingly lower, than in the sandstone.

The micro-vent is one of several burrows found in the sandstone specimen. Only one or two others cut through the bed bottom to top. These are much narrower. At the vent the bed is transected by a zone of disturbance of lamination, originating as micro-faults on the basal surface (fig. 1B). This is taken to be due to differential compaction of the underlying clay bed. Evidently, the vent could function as an outlet for escaping

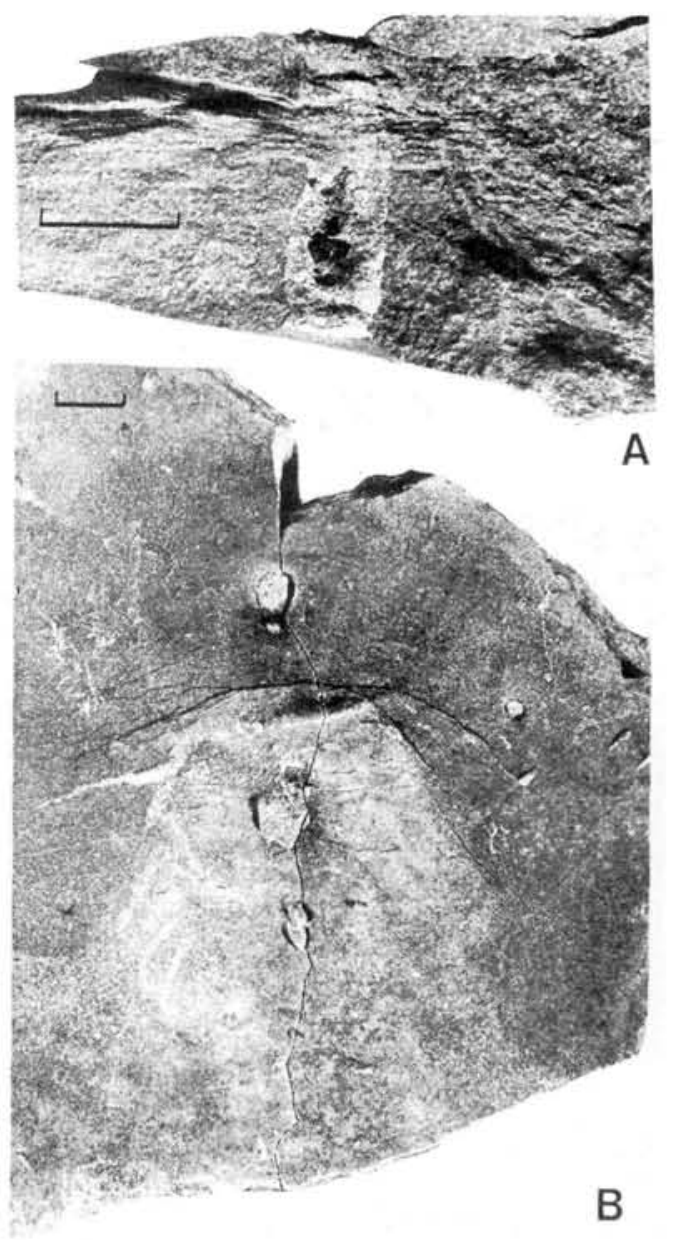

Fig. 1. Lower Cambrian Mickwitzia Sandstone, Lugnàs, Sweden. A. Cross section, normal orientation, micro-vent (pale) with sphalerite. B. Lower surface of bed, with fracture shown in $A$. The pipe shown in $A$ is the uppermost of 3 along the fracture. Note compactional micro-faults. $A$ and $B$ illuminated from below. Scale $=1 \mathrm{~cm}$.

water, and possibly for sediment as well. The sandstone probably was less permeable because of its content of clay and horizontally layered muscovites.

The sphalerite forms a closed aggregate of crystals the size of which reaches a few $\mathrm{mm}$. There are also scattered smaller crystals in the matrix of the micro-vent. Identification was made by opti$\mathrm{cal}$ and $\mathrm{X}$-ray methods. The colour varies from nearly colourless to saturated yellowish brown; in general, it is stronger than in the Upper Silurian specimen. There are a few purplish stripes that are probably due to trace elements (Graeser 1971). 


\title{
Sphalerite from transgressive and regressive sediments of the Cambro-Silurian supercycle, Baltic Shield
}

\author{
MAURITS LINDSTRÖM \& W, VORTISCH
}

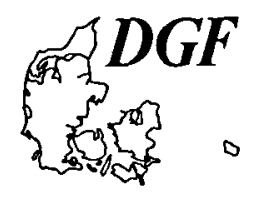

\begin{abstract}
Lindström, M. \& Vortisch, W. 1978: Sphalerite from transgressive and regressive sediments of the Cambro-Silurian supercycle, Baltic Shield. Bull. geol. Soc. Denmark, vol. 26, p. 47-53. Copenhagen, October 1st 1978.

A sedimentary micro-vent in Lower Cambrian sandstone, and spar filled cephalopod shells in uppermost Wenlockian barite and dolomite carrying silty pelmicrosparite contain well-developed macroscopic $\mathrm{ZnS}$-mineralization and very little pyrite. As controlling factors are suggested, good permeability, availability in underlying sediment of finely dispersed organic matter with sorbed $\mathrm{Zn}$, and low $\mathrm{S}^{2-}$ activity in the percolating water. Sedimentation was temporarily rather rapid.
\end{abstract}

M. Lindström \&W. Vortisch, Institut für Geologie und Paläontologie, Philipps-Universität, Marburg, Lahnberge, D-3550 Marburg, F.R.G. December 6th, 1977.

Macroscopic zincblende is rare in the Cambro-Silurian of the Baltic Shield. We can report on two cases of sphalerite, both apparently of a relatively early, diagenetic origin. Significantly, they occur in the Lower Cambrian and upper Middle Silurian, in the transgressive and regressive phases of Early Palaeozoic marine sedimentation in northern Europe. Structure and mineralogy of the rocks appear to indicate some interesting restrictions on the interpretation.

For reviews of the Early Palaeozoic of the Baltic Shield, see for instance Lindström 1971 and Magnusson et al. 1960. In the Early Cambrian the sea transgressed on peneplaned terrains of mostly igneous and metamorphic rocks, depositing a sheet of quartzitic to feldspathic sands and silts, and more or less potash-rich clays. During later parts of the Cambrian a regime of black mud, rich in pyrite and organic carbon, became universally established. In the Early Ordovician this was succeeded by mainly limestones, very slowly deposited, of a type that one might characterize as pelagic. In the Middle and Late Ordovician the sedimentation of terrigenous mud accelerated slightly, resulting in a number of shaly members, some of which are graptolithic. Calcareous mounds are a feature of some areas. As in several other regions, the sea obviously withdrew for a relatively short interval at the Ordovician/Silurian transition. Silurian sediments were for the most part deposited in warm, nutrient rich shelf waters of slight to medium depth. This resulted in variable, mainly calcareous fa- cies, ranging from fossiliferous marls through reef and algal limestones, coquinoid bioclastics, oolites and siltstones, to fine to medium grained sandstones. Together with the oolites the latter represent regressive phases (see, e.g., Regnéll \&. Hede 1960). About the Silurian/Devonian transition the sea ultimately withdrew towards the south. At this stage much, if not most, of the Baltic Shield was covered by a flat-lying sheet of Lower Palaeozoic sediments, the thickness of which attained a few hundred metres at the southern border.

\section{A Lower Cambrian specimen}

Sphalerite was found in a $5-6 \mathrm{~mm}$ thick micro-vent transecting a $1-3 \mathrm{~cm}$ thick bed of sandstone belonging to a succession of alternating sandstone and clay beds at the base of the Lower Cambrian "Mickwitzia Sandstone" of Lugnås old millstone quarry (now an open-air museum), Västergötland, Sweden (see, for instance, Hadding 1922). The sandstone rests on a plane surface of gneiss that is kaolinized and somewhat silicified down to a depth of a several tens of centimetres. The basal conglomerate may be some $10-30 \mathrm{~cm}$ thick and contain pebbles of e.g. vein quartz, potash feldspar, clay ironstone, and sandstone with a reddish, ferruginous cement. Then follow several metres of alternating beds of ripple cross-bedded sandstone, mostly a few centimetres thick, and grey, silty kaolinite and illite 
containing clay (X-ray), mostly somewhat thinner than the sandstone beds. The sandstone beds are common in the lowermost metre. The sample comes from this interval.

It is a silty, cross-laminated sandstone with grain-sizes mainly $10-150 \mu \mathrm{m}$ and few grains over $500 \mu \mathrm{m}$. Quartz, feldspar (mainly K-feldspar (X-ray), some plagioclase) and muscovite are the main components. Zircon and tourmaline are not rare, and a few rutiles occur. Electron Probe Analysis (EPA) revealed the presence of $\mathrm{TiO}_{2}$, probably mainly as anatase (by optical and X-ray comparison with Lower Cambrian sandstone in southernmost Sweden, see Vortisch 1975). This mineral is probably authigenic.

Remnants of ferrous sulphide were identified as probably pyrite. The matrix consists of siderite, illitic and kaolinitic clay minerals (X-ray), and yellowish brown colouring matter, presumably ferric oxyhydrate. The latter could not be identified by X-ray and might be present in small quantities. The siderite is seldom clear but appears mixed with clay minerals and brownish colouring substance. In the thin section the sedimentary lamination is seen to consist of aggregates of clastic grains, mostly cemented by quartz, separated by siderite cemented floccules of clay and isolated clastic grains. The siderite has eaten into many of the clastic grains and their quartz cement.

The siderite mostly contains about $0.5 \% \mathrm{Mn}$ by weight (EPA). Mn contents of ca $3-6 \%$ were identified at some spots.

The micro-vent (fig. 1A), presumably a vertical burrow that took over transporting functions between the lower and upper surfaces of the sandstone layer, is distinguished from the latter by its pale greenish grey colour. The content of clay minerals (illite, kaolinite) and microclinelike potash feldspar is appreciably higher, and the quartz and siderite content correspondingly lower, than in the sandstone.

The micro-vent is one of several burrows found in the sandstone specimen. Only one or two others cut through the bed bottom to top. These are much narrower. At the vent the bed is transected by a zone of disturbance of lamination, originating as micro-faults on the basal surface (fig. 1B). This is taken to be due to differential compaction of the underlying clay bed. Evidently, the vent could function as an outlet for escaping

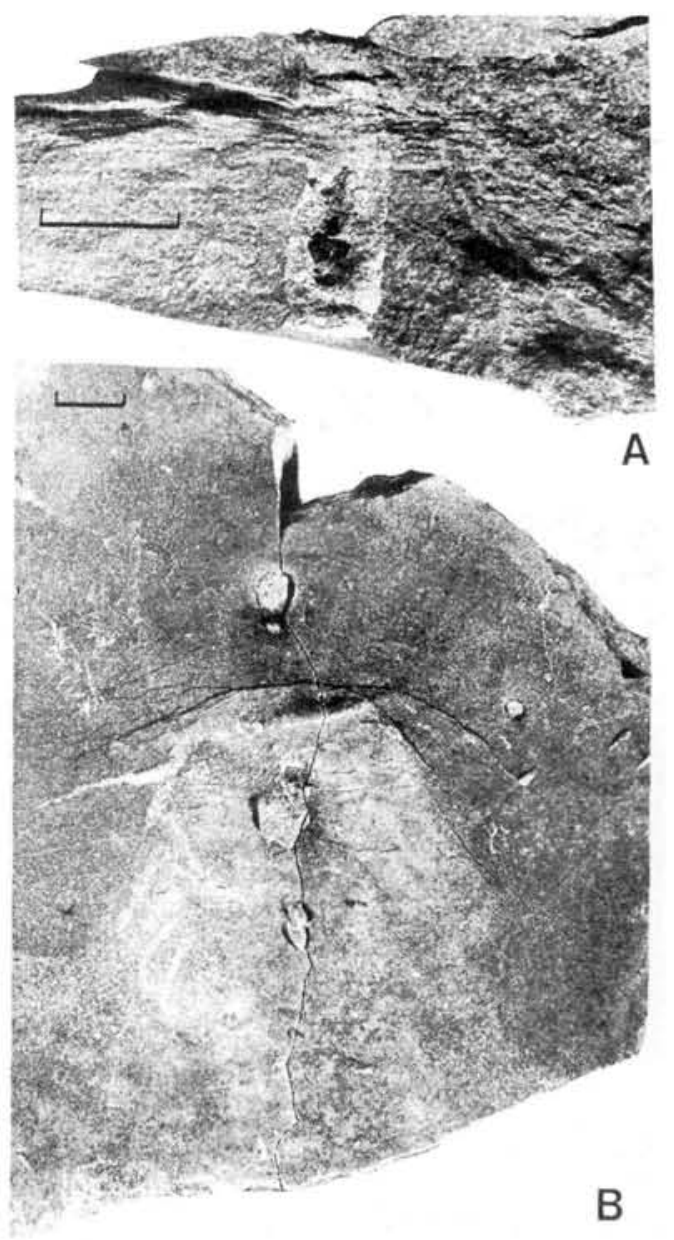

Fig. 1. Lower Cambrian Mickwitzia Sandstone, Lugnàs, Sweden. A. Cross section, normal orientation, micro-vent (pale) with sphalerite. B. Lower surface of bed, with fracture shown in $A$. The pipe shown in $A$ is the uppermost of 3 along the fracture. Note compactional micro-faults. $A$ and $B$ illuminated from below. Scale $=1 \mathrm{~cm}$.

water, and possibly for sediment as well. The sandstone probably was less permeable because of its content of clay and horizontally layered muscovites.

The sphalerite forms a closed aggregate of crystals the size of which reaches a few $\mathrm{mm}$. There are also scattered smaller crystals in the matrix of the micro-vent. Identification was made by opti$\mathrm{cal}$ and $\mathrm{X}$-ray methods. The colour varies from nearly colourless to saturated yellowish brown; in general, it is stronger than in the Upper Silurian specimen. There are a few purplish stripes that are probably due to trace elements (Graeser 1971). 
rial, som för en tid har blivit bevarat i de relativt snabbt avlagrade sedimenten. Ursprungligen kom den förmodligen från berggrund, som vittrade $\mathrm{i}$ närliggande landområden på den baltiska skölden.

\section{References}

Barton, P. B. Fr. \& Toulmin, R. III 1966: Phase relations involving sphalerite in the $\mathrm{Fe}-\mathrm{Zn} \mathrm{S}$ System. Econ. Geol. 65 : 815-849.

Berner, R. 1970: Iron, G-L. In Wedepohl, K. H. (ed.) Handbook of Geochemistry, II $-2,26, \mathrm{G}-1-\mathrm{L}-3$, Berlin, Heidelberg, New York: Springer.

Boström, K., Joensuu, O. \& Brohm, I. 1975: Plankton, its chemical composition and its significance as a source of pelagic sediments. Chem. Geol. 14: 255-271.

Boyle, R. W. \& Lynch, J. J. 1968: Speculations on the source of zinc, cadmium, lead, copper and sulfur in Mississippi Valley and similar types of lead-zinc deposits. Econ. Geol. 63: 421-422.

Graeser, S. 1971: Mineralogisch-geochemische Untersuchungen an Bleiglanz und Zinkblende. Schweiz: Min. Petr. Mitt. 51: 415-442.

Hadding, A. 1929: The pre-Quaternary sedimentary rocks of Sweden. II. The paleozoic and mesozoic sandstones of Sweden. Lunds Univ. Arsskr. N.F., 25 (3): 287 pp.

Hallberg, R. O. 1968: Some factors of significance in the formation of sedimentary metal sulphides. Stockholm Contrib. Geol. 15: 39-66.

Hede, J. E. 1921: Gottlands silurstratigrafi. Sveriges Geol. Unders. (C) 305: $100 \mathrm{pp}$.

Jones, K. \& Hirst, D. M. 1971: The distribution of barium, lead and zinc in the Lower and Middle Magnesian Limestone of County Durham, Great Britain. Chem. Geol. 10: 223-236.

Laufeld, S. 1974a: Reference localities for palaeontology and geology in the Silurian of Gotland. Sveriges Geol. Undersökn. (C) 705: $150 \mathrm{pp}$.

Laufeld, S. 1974b: Preferred orientation of orthoconic nautiloids in the Ludlovian Hemse Beds of Gotland. Geol. Fören. Stockholm Förhandl. 96: 157-162.

Lindström, M. 1971: Vom Anfang, Hochstand und Ende eines Epikontinentalmeeres. Geol. Rundschau 60: 419-438.

Love, L. E. 1969: Sulphides of metals in recent sediments. Proc. 15th Inter-University Geological Congress, Leicester 1967: 31-60.

Magnusson, N. H., Thorslund, P., Brotzen, F., Asklund, B. \& Kulling, O. 1960: Description to accompany the map of the pre-Quaternary rocks of Sweden. Sver. Geol. Undersökn. (Ba) 16: $177 \mathrm{pp}$.

Regnéll, G. \& Hede, J. E. 1960: The Lower Palaeozoic of Scania, The Silurian of Gotland. Internat. Geol. Congr. 21 Session Nord 1960, Guide Excursions A22, C17: 87 pp.

Temple, K. K. \& Le Roux, N. W. 1964: Syngenesis of sulphide ores: desorption of adsorbed metal ions and their precipitation as sulphates. Econ. Geol. 59: 647-655.

Tröger, W. E. 1969: Optische Bestimmung der gesteinsbildenden Minerale, 2, Textband. 2nd ed., 822 pp. Stuttgart: Schweizerbart.

Vortisch, W. 1975: Schwermineralkonzentrationen im Unterkambrium SO-Schonens (Schweden). Beobachtungen zur Sedimentation und Diagenese. N. Jb. Geol. Paläont. Abh. 150: 44-72.

Wedepohl, K. H. 1972: Zinc, B-O. - In Wedepohl, K. H. (ed.):

- Handbook of Geochemistry, II-2, B1 - O2, Berlin, Heidelberg, New York: Springer. 
The average Fe content according to EPA determination is about $1-1.6 \%$. Other elements that might influence the lattice constant $a_{o}$ were not found in significant quantities. Thus Cd occurs in traces close to the limit of demonstrability (one spot however had ca $0.5 \% \mathrm{Cd}$ ). $\mathrm{Cu}$ and $\mathrm{Mn}$ could not be proven to occur. Hence, the average $\mathrm{Fe}$ content might theoretically be calculated through $a_{o}$ determined by $X$-ray diffractometry. For the sake of simplicity, $a_{0}$ was determined by first calibrating the $d$ value of the (422) reflexion of the sphalerite by the two neighbouring quartz reflexions, (311) and (312) (Philips X-ray powder diffractometer, graphite monochromator, CuK $\alpha$ radiation, scanning speed: $1 / 2^{\circ} 20 / \mathrm{min}$, mean of 5 measurements). The FeS content was calculated using the formula of Barton \& Toul$\min (1966)$. The exactitude of this Fe determination is very limited, since the standard deviation of single measurements is of about the same order as the Fe content. The mean $a_{o}$ determination was $5.4109 \AA$, which would correspond to 2.9 mo1\% FeS. This might not be too far from the actual amount.

For the interpretation of the sphalerite the relation to the ferruginous mineral phases is important. Thus, Fe was present at least in glauconite and pyrite, before cementation by siderite took place. Siderite cement, while partially replacing many quartz and feldspar grains, is itself replaced by the quartz cement. The oxidation of the siderite cement is difficult to date relative to quartz cementation.

\section{An Upper Silurian specimen}

The specimen is from a thin-bedded silty limestone in the uppermost Slite Beds (upper Wenlockian) at the shore NW of Gandarve, Gotland. The locality is dealt with as "Klinteenklaven" in Laufeld (1974a). Silty limestone and more or less calcareous siltstone are sporadically exposed in horizontal outcrops, parallel to the bedding. They are laminated, with little bioturbation, and a few simple trace fossils on some surfaces. Current lineation, groove marks, frondescent load structures, and lenticular small-scale cross-bedding are characteristic features. The fauna is rather poor in species (Hede 1921). It comprises Chonetes cingulatus, Plagiorhyncha cordata, both of which may be abundant, pelecypods, gastropods, ostracodes, a few graptolites, and aligned orthoconic cephalopods. A similar occurrence was described from the Ludlovian uppermost Hemse Beds of Gotland by Laufeld (1974b), who drew conclusions about a near shoreline situation from the orientation of cephalopods.

The uppermost Slite Beds immediately predate a phase of sandy deposition and formation of calcareous oolite and pisolites near the Wenlockian-Ludlovian transition. They were no doubt formed in very shallow water, although the proximity to the shoreline may be an open question.

The specimen is a $4 \mathrm{~cm}$ thick bed of massive, matrix supported calcareous pelmicrosparite with abundant grains of barite, quartz, and dolomite, all in the range about $20-50 \mu \mathrm{m}$, and with very numerous bioclasts ranging in size from about 50 $\mu \mathrm{m}$ to several $\mathrm{cm}$. The bioclastic population is dominated by entire, single shells of articulate brachiopods, following by orthoconic cephalopods, arthropods, and bryozoans. Ca $27 \%$ of the rock is insoluble in cold dilute $\mathrm{HCl}$.

An estimated $10-25 \%$ of the rock consists of micritic to microsparitic pellets averaging about $50 \mu \mathrm{m}$ in diameter. Dolomite has been identified in rhombohedra that occur in abundance scattered throughout the rock. Their size is some 30-50 $\mu \mathrm{m}$. Some of them have a thin coating of an opaque mineral that has been identified (EPA and reflected light) as probably pyrite. Dolomite also occurs as cement in small, irregularly delimited enclaves within the rock. Locally, an indication of ankerite was found by EPA.

Of the non-carbonates, pyrite, referred to above, occurs in very small amounts. On the other hand, barite is common. It forms ca $2.5-3 \%$ of the rock. It occurs as angular granules, some of which are developed as idiomorphic crystals, mostly in the size range $10-50 \mu \mathrm{m}$, and as cement and cavity filling. In the latter capacity it may enclose granules of the same mineral, as well as dolomite rhombs. In one case barite cement was found to have been concentrated on the upper face of a shell, whereas an adjacent lower face was coated with clear calcite spar. This suggests gravity separation of detrital barite (see below). Partial replacement of dolomite rhombohedra by barite was observed in several places.

Further minerals are, quartz that appears to be 



Fig. 2. Uppermost Slite Beds, Gannarve, Gotland, Sweden. Silty dolomite limestone with orthocone cephalopod, filled with calcite and a sphalerite inclusion. Note strand of (originally aragonitic?) mamelons along trace of siphonal tube (middle, right). Scale: 1 $\mathrm{cm}$.

largely clastic, feldspar ( $\mathrm{K}$ feldspar and acid plagioclase indicated by $\mathrm{X}$-ray), clay minerals ( $\mathrm{X}$-ray identification of illitic and kaolinitic components), muscovite, a few small spots of $\mathrm{TiO}_{2}$ (anatase or brookite?), phosphatic material of biogenic origin.

Sphalerite occurs as major aggregates (several $\mathrm{mm}$ in diameter) mainly within the orthocone cephalopods (fig. 2), and as scattered small aggregates. Few traces of the cephalopod shells themselves can be found, but the whole inner ca- vity and the space left after dissolution of the shell was filled by the same large calcite spars and sphalerite. In places, the inner cavity was invaded by sediment from outside, before calcite and sphalerite crystallized. In the calcitic parts the early sediment filling may be almost intact. The sphalerite, however, has replaced the early filling almost totally, only a few dolomite rhombs and quartz granules remaining within the crystals.

The Slite Beds sphalerite is predominantly colourless or faintly yellowish. This suggests a lower $\mathrm{Fe}$ content than in the case of the Mickwitzia Sandstone. As is the case in the Lower Cambrian sphalerite, there are strongly purplish parts that are due to the presence of trace elements other than $\mathrm{Fe}$. $\mathrm{Fe}$ and $\mathrm{Cd}$ contents are close to the lower limit of the range identifiable by EPA (ca. $0.1 \% \mathrm{Fe}$ ) (fig. 3). As in the Lower Cambrian sample, $\mathrm{Cu}$ and $\mathrm{Mn}$ could not be identified. The $\mathrm{FeS}$ content obtained through X-ray $\mathrm{a}_{\mathrm{o}}$ determination $(5.4099 \AA)$ was $1.1 \mathrm{~mol} \%$. The discrepancy between this value and the EPA determination of $\mathrm{Fe}$ is within the probable error of the $\mathrm{X}$-ray method.

The following sequence of main events can be assumed for the investigated sample:

1. Sedimentation of bioclasts, pellets, non-carbonatic clasts including small barites, and dolomite rhombs.

2. Re-distribution of barite within the sediment, including replacement of dolomite rhombs by barite and formation of barite cement, some cementation by calcite (and aragonite? indicated by mamelons of possibly aragonitic original composition on preserved parts of a cephalopod shell).

3. Solution of cephalopod shells.

4. Filling of cephalopod shells by calcite spar and sphalerite.

\section{Discussion}

The two described sphalerite occurrences share a combination of features that render them significant.

1. They are non-hydrothermal and diagenetic.

2. There are no other sulphide phases of any importance. 

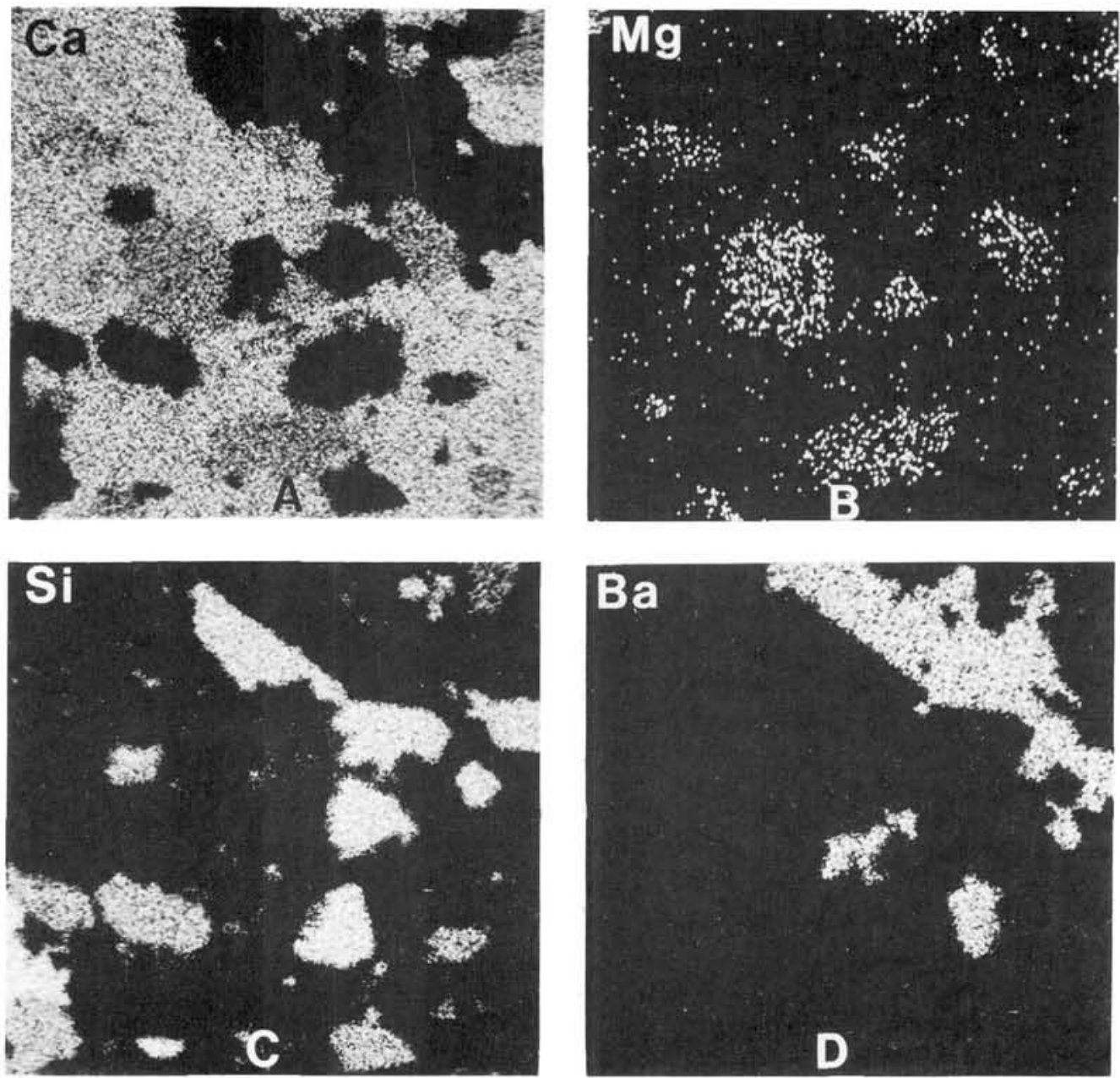

Fig. 3. Electron probe micrographs, ca X 220, of Slite Beds, silty dolomitic limestone. A. Distribution of $\mathrm{Ca}$, note reduced density of indications in $\mathrm{Mg}$-rich areas, corresponding to dolomite. B. Distribution of $\mathrm{Mg}$, corresponding to dolomite grains, C. Distribution of Si, corresponding mainly to quartz (greater density; in

part authigenic at upper middle-right), and feldspar (lesser density, for instance at lower left and lowermost middle-right). $D$. Distribution of Ba; note crystal face boundary against $\mathrm{Si}$; compare with $C$.

3. They are associated with other diagenetic minerals (siderite, barite) formed under physicochemical conditions other than those prevalent during sphalerite crystallization.

4. They formed on a very flat, very extensive, and very shallow sea-bed.

5. They are associated with rather abundant, detrital quartz and silicate of silt to sand size.

In view of the circumstance that iron and zinc are about equally concentrated in sea water as well as in organisms occurring in the sea (Wedepohl 1972, Berner 1970, Boström, Joensuu \& Brohm 1975) it appears unexpected that sphale-

rite should occur alone as a diagenetic sulphide, almost without accompanying pyrite. In most cases the availability of iron is much greater than that of zinc, because of abundant supply of non-dissolved $\mathrm{Fe}$ that can enter the solution as the latter is deprived of Fe through sulphide precipitation.

Jones \& Hirst (1971) have pointed out the positive importance of rock permeability for zinc enrichment as sulphide in Permian limestones in northern England. Whereas highly porous reef

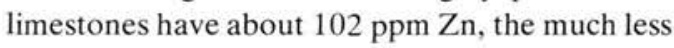
porous basin facies has 2-4 ppm. Hallberg (1968) 
by a different approach concluded about the negative importance of lacking porosity for sulphide generation in sea-bed sediments.

The Cambrian micro-vent and the Silurian empty cephalopod shells must have been highly suitable environments for sulphide precipitation. However, this would have applied equally well for pyrite as for sphalerite.

The presence of partly unweathered clastic components together with the geographic and stratigraphic situation indicate that the zinc of both samples ultimately came from magmatic bedrock on the Baltic Shield. However, the same source must have furnished even more iron.

The non-sulphides present in both samples may provide certain clues. Siderite and barite have in common that they indicate very low sulphide activity. in the solution. The barite of the Silurian sample may have been enriched as detrital grains of mostly very small sizes, possibly derived from gentle reworking of older sediments (see Tröger 1969 for a balanced opinion on this possibility). It obviously was present before the precipitation of sphalerite and would scarcely have withstood strong activity of sulphate reducing bacteria. Siderite cementation of the Lower Cambrian sample was probably completed after percolation through the sphalerite-carrying micro-vent had ceased, but might well have begun before this. If this was the case, the environment would have been unsuitable for pyrite precipitation.

Organisms enrich zinc in their soft parts. In particular, this appears to be the case in certain mollusks. Oysters may contain as much as ca $1 \%$ Zn (Boyle \& Lynch 1968). Except for the disintegrated cephalopod shells, there are no traces of mollusks in any of the samples, but this need not necessarily indicate that they were absent. In general, however, the Lower Cambrian sandstone is very poor in body fossils, and bioturbation of the sediment is everywhere weak.

Because sea water is poor in zinc, it is probable that the immediate main source of the zinc was sedimental organic detritus of plant or animal origin. This easily contains a hundredfold to thousandfold of the zinc occurring in solution (Wedepohl 1972, Boström, Joensuu \& Brohm 1975). On desorption from such material owing to formation of sulphide, zinc would apparently be preferred to iron (Love 1969, Temple \& Le
Roux 1964). The ionic activity of zinc sulphide is several orders less than that of ferric sulphide under similar physicochemical conditions. At a sufficiently low concentration of sulphide ions, sphalerite, rather than pyrite, would thus form as a consequence of desorption from organic material.

In the case of the Cambrian micro-vent the organic carriers of zinc were probably brought by water extruded from the underlying clay and silt bed as this was compacted. Traces of the compaction movements are visible as pre-cementation micro-faults at the base of the sandstone bed. In the Silurian instance the organic material may either have existed in underlying beds or within the sphalerite containing bed itself. The former alternative is the more likely one in view of the preservation of the barite. In both cases, the retention of sufficient quantities of organic material within the sediment was probably due to the conditions of relatively rapid sedimentation in the transgressive and regressive phases of the Early Palaeozoic supercycle. Slower sedimentation would have allowed the zinc carriers to be destroyed at the sediment/water interface. The redox potential was in the critical range for the survival of sulphide ions at the given rate of production.

Acknowledgements. K. Fecher, Marburg, helped with the electron probe analyses. Dr. G. Amthauer, Mineralogy Department, Marburg, read the manuscript and offered constructive criticism.

\section{Svensk sammendrag}

Stora, välutbildade sfaleritkristaller har påträffats $i$ ett litet sedimentärt eruptionsrör $i$ den underkambriska mickwitziosandstenen $i$ Lugnås och $i$ hålrumsfyllnader $i$ en orthoceratitförande kalksten ur de översta sliteskikten vid Gandarve på Gotland. Dessa fynd är intressanta därför att (1) zinksulfiden är diagenetisk och inte hydrotermal, (2) andra sulfider praktiskt taget saknas, (3) beledsagande mineral (siderit, barit) kräver en annan kemisk bildningsmiljö, (4) bildningsmiljöerna har gemensamma drag, t.ex. ytterst långgrunt vatten och rikligt terrigent material av omkring sandstorlek och närmast därunder. I regel förekommer zinksulfid tillsamman med pyrit, eftersom järn är tillgängligt för sulfidbildning i större mängd än zink. Siderit och barit bildas i miljöer, som i regel är mycket fattiga på sulfidjoner. Då zinksulfid är ännu mycket svårlösligare än jänrsulfid, är det möjligt, at den $\mathbf{i}$ de diskuterade fallen har utfällts $\mathrm{i}$ miljöer, som var relativt rika på zink men fattiga på sulfidjoner. Zinken kan ha varit löst bunden vid organisk mate- 
rial, som för en tid har blivit bevarat i de relativt snabbt avlagrade sedimenten. Ursprungligen kom den förmodligen från berggrund, som vittrade $\mathrm{i}$ närliggande landområden på den baltiska skölden.

\section{References}

Barton, P. B. Fr. \& Toulmin, R. III 1966: Phase relations involving sphalerite in the $\mathrm{Fe}-\mathrm{Zn} \mathrm{S}$ System. Econ. Geol. 65 : 815-849.

Berner, R. 1970: Iron, G-L. In Wedepohl, K. H. (ed.) Handbook of Geochemistry, II $-2,26, \mathrm{G}-1-\mathrm{L}-3$, Berlin, Heidelberg, New York: Springer.

Boström, K., Joensuu, O. \& Brohm, I. 1975: Plankton, its chemical composition and its significance as a source of pelagic sediments. Chem. Geol. 14: 255-271.

Boyle, R. W. \& Lynch, J. J. 1968: Speculations on the source of zinc, cadmium, lead, copper and sulfur in Mississippi Valley and similar types of lead-zinc deposits. Econ. Geol. 63: 421-422.

Graeser, S. 1971: Mineralogisch-geochemische Untersuchungen an Bleiglanz und Zinkblende. Schweiz: Min. Petr. Mitt. 51: 415-442.

Hadding, A. 1929: The pre-Quaternary sedimentary rocks of Sweden. II. The paleozoic and mesozoic sandstones of Sweden. Lunds Univ. Arsskr. N.F., 25 (3): 287 pp.

Hallberg, R. O. 1968: Some factors of significance in the formation of sedimentary metal sulphides. Stockholm Contrib. Geol. 15: 39-66.

Hede, J. E. 1921: Gottlands silurstratigrafi. Sveriges Geol. Unders. (C) 305: $100 \mathrm{pp}$.

Jones, K. \& Hirst, D. M. 1971: The distribution of barium, lead and zinc in the Lower and Middle Magnesian Limestone of County Durham, Great Britain. Chem. Geol. 10: 223-236.

Laufeld, S. 1974a: Reference localities for palaeontology and geology in the Silurian of Gotland. Sveriges Geol. Undersökn. (C) 705: $150 \mathrm{pp}$.

Laufeld, S. 1974b: Preferred orientation of orthoconic nautiloids in the Ludlovian Hemse Beds of Gotland. Geol. Fören. Stockholm Förhandl. 96: 157-162.

Lindström, M. 1971: Vom Anfang, Hochstand und Ende eines Epikontinentalmeeres. Geol. Rundschau 60: 419-438.

Love, L. E. 1969: Sulphides of metals in recent sediments. Proc. 15th Inter-University Geological Congress, Leicester 1967: 31-60.

Magnusson, N. H., Thorslund, P., Brotzen, F., Asklund, B. \& Kulling, O. 1960: Description to accompany the map of the pre-Quaternary rocks of Sweden. Sver. Geol. Undersökn. (Ba) 16: $177 \mathrm{pp}$.

Regnéll, G. \& Hede, J. E. 1960: The Lower Palaeozoic of Scania, The Silurian of Gotland. Internat. Geol. Congr. 21 Session Nord 1960, Guide Excursions A22, C17: 87 pp.

Temple, K. K. \& Le Roux, N. W. 1964: Syngenesis of sulphide ores: desorption of adsorbed metal ions and their precipitation as sulphates. Econ. Geol. 59: 647-655.

Tröger, W. E. 1969: Optische Bestimmung der gesteinsbildenden Minerale, 2, Textband. 2nd ed., 822 pp. Stuttgart: Schweizerbart.

Vortisch, W. 1975: Schwermineralkonzentrationen im Unterkambrium SO-Schonens (Schweden). Beobachtungen zur Sedimentation und Diagenese. N. Jb. Geol. Paläont. Abh. 150: 44-72.

Wedepohl, K. H. 1972: Zinc, B-O. - In Wedepohl, K. H. (ed.):

- Handbook of Geochemistry, II-2, B1 - O2, Berlin, Heidelberg, New York: Springer. 